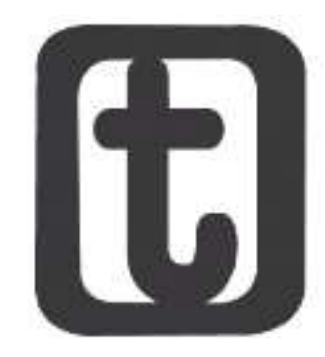

\title{
CAPITALISMO DEPENDENTE, AUTOCRACIA BURGUESA E DEMOCRACIA DE COOPTAÇÃO: O GOLPE DE 2016 E A ATUALIDADE DE FLORESTAN FERNANDES
}

\author{
Dependent capitalism, burgish autocracy and cooptation democracy: the 2016 coup and \\ current Florestan Fernandes
}

\section{Davi Machado Perez*}

\section{RESUMO}

O presente artigo, resultado de pesquisa bibliográfica e documental, aborda a interpretação do sociólogo brasileiro Florestan Fernandes acerca da formação sócio histórica do Brasil objetivando debater sua atualidade para a compreensão socioeconômica e política do Brasil contemporâneo, com destaque para o golpe de Estado de 2016. Conclui-se que o capitalismo dependente e as combinações entre autocracia burguesa e democracia de cooptação seguem vigentes na realidade brasileira.

\section{PALAVRAS-CHAVE}

Florestan Fernandes; Golpe de Estado; Capitalismo dependente; Autocracia burguesa; Democracia de cooptação.

\section{ABSTRACT}

The present article, a result of bibliographical and documentary research, approaches the interpretation of the Brazilian sociologist Florestan Fernandes about the socio - historical formation of Brazil aiming to discuss its relevance to the socioeconomic and political understanding of contemporary Brazil, especially the coup of 2016. It is concluded that dependent capitalism and the combinations between bourgeois autocracy and democracy of cooptation are still valid in the Brazilian reality.

\section{KEYWORDS}

Florestan Fernandes; Coup D'etat; Dependent capitalism; Bourgeois autocracy; Democracy of cooptation.

\section{INTRODUÇÃO}

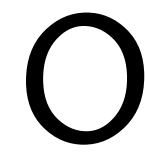

tema da formação sócio histórica do Brasil constitui um dos três núcleos que conformam as diretrizes curriculares do Serviço Social brasileiro. Este enfoque possibilita situar o debate da processualidade histórica da 'questão social' e suas

\footnotetext{
* Assistente Social. Doutor em Serviço Social. Docente do curso de Serviço Social da Universidade Federal do Tocantins (UFT, Miracema, Brasil). Av. Lourdes Solinho, 195 - St. Sussuapara, Miracema do Tocantins (TO), CEP.: 77650-000. ORC ID: <http://orcid.org/0000-0003-0267-2380>. E-mail:<daviperez1987@gmail.com>.
}

\section{DOI 10.22422/temporalis.2019v19n37p10-25}

\section{(cc) $\mathrm{Br}$}

(c) A(s) Autora(s)/O(s) Autor(es). 2019 Acesso Aberto Esta obra está licenciada sob os termos da Licença Creative Commons Atribuição 4.0 Internacional (https://creativecommons.org/licenses/by/4.o/deed.pt_BR), que permite copiar e redistribuir o material em qualquer suporte ou formato, bem como adaptar, transformar e criar a partir deste material para qualquer fim, mesmo que comercial. O licenciante não pode revogar estes direitos desde que você respeite os termos da licença.

Temporalis, Brasília (DF), ano 19, n. 37, p. 28-44, jan./jun. 2019. | ISSN 2238-1856 
multifacetadas expressões articulando o entendimento das características universais da sociedade capitalista com suas particularidades expressas na realidade brasileira. Análise esta que se direciona para a apreensão dos movimentos que permitiram a consolidação de determinados padrões de desenvolvimento capitalista no país, bem como os impactos econômicos, sociais e políticos peculiares à sociedade brasileira (ASSOCIAÇÃO BRASILEIRA DE ENSINO E PESQUISA EM SERVIÇO SOCIAL, 1996).

Ao longo de nosso processo de formação em Serviço Social tematizamos reiteradamente a necessidade de compreender as particularidades da 'questão social' no Brasil. Quais os limites e potencialidades para a emancipação política e humana se apresentam no quadro da realidade socioeconômica e política brasileira? Na busca por desvelar essa problemática se fez presente para nós a referência em Florestan Fernandes, com a originalidade e o realismo de sua compreensão sobre a revolução burguesa e o capitalismo dependente no Brasil, resultando na pesquisa bibliográfica e documental que constituiu nossa tese de doutorado.

Considerada rigorosamente marxista por José Paulo Netto (2013), a interpretação florestaniana do Brasil tem sua expressão mais abrangente no ensaio A revolução burguesa no Brasil, elaborado a partir de 1966 e publicado em 1974. Trata-se de uma monumental contribuição que é resultado de um denso acúmulo de estudos e pesquisas teóricos e empíricos, cujo fio condutor sempre manteve a preocupação em desvendar a realidade brasileira e a posição dos setores explorados e oprimidos diante das contradições societárias apresentadas. Categorias centrais como escravismo, revolução burguesa, capitalismo dependente, imperialismo total, autocracia burguesa e democracia de cooptação relacionam-se na obra do sociólogo e conformam um eixo de análise fundamental para a compreensão de nossa formação sócio histórica.

Neste artigo, buscamos primeiramente apresentar uma síntese da interpretação florestaniana do Brasil, para posteriormente abordar a atualidade de sua contribuição para a compreensão da transição pós-ditadura civil-militar que conformou o atual regime político vigente, o caráter da formação social e do Estado brasileiro em suas expressões contemporâneas, perpassando o processo constituinte e o contexto que culminou no golpe de Estado de 2016.

\section{A INTERPRETAÇÃO FLORESTANIANA DO BRASIL}

Quando elabora a obra A revolução burguesa no Brasil, Florestan Fernandes opta pelo ensaio, forma de exposição mais abrangente que permite a afirmação de convicções teórico-políticas para além das especificidades exigidas nos estudos tópicos anteriores. Ocorre, por fim, a plena fusão do marxista e do sociólogo acadêmico. A práxis de Fernandes se consolida e sua obra vai abordar os grandes temas que interessam para a compreensão e transformação do Brasil e da América Latina'. Este é, portanto, um ponto de chegada no processo de construção de sua interpretação do Brasil.

\footnotetext{
${ }^{1} \mathrm{Na}$ fase inicial da trajetória acadêmica de Fernandes há, segundo Souza (2001), uma 'dualidade' entre o acadêmico e o militante, sendo que ao mesmo tempo uma estrutura paralela ou rio subterrâneo crítico e marxista em amadurecimento corre ao longo de toda trajetória. Na segunda metade dos anos 1960, após sofrer as consequências do aumento da repressão no interior da ditadura civil-militar e exilar-se, há uma superação dessa 'aparente dualidade' e o marxismo emerge explicitamente em sua posição acadêmica.
} 
Além da determinante influência de Marx e da utilização crítica de categorias de Weber, é marcante em A revolução burguesa no Brasil a influência de Lênin em seus estudos sobre o imperialismo e a particularidade do desenvolvimento capitalista na Rússia. Assim como Lênin analisou os limites da burguesia russa, incapaz de cumprir plenamente tarefas nacionais e democráticas que nos países centrais foram cumpridas na revolução burguesa, Florestan buscou identificar historicamente os empecilhos estruturais e o caráter de nossa burguesia. A apropriação rigorosa do método dialético permitiu ao autor não cair em conclusões extremas e extravagantes, mostrando que tivemos uma revolução burguesa atípica que consolidou uma forma particular de desenvolvimento capitalista.

A compreensão de Lênin (1988, p. 13) que considera a gradual transformação da economia mercantil simples em economia capitalista, a análise a respeito das vias não clássicas de revolução burguesa ${ }^{2}$, além da própria conceituação de autocracia (reelaborada pelo sociólogo na formulação da autocracia burguesa) sem dúvida são determinantes na concepção de Florestan Fernandes. Esta inspiração não significa que o autor faça algum tipo de transposição da realidade russa ou europeia para a realidade brasileira, e é justamente por isso que categorias utilizadas por Lênin como via prussiana não aparecem em seu ensaio, pois a formulação de sua interpretação do Brasil exigia a construção de categorias próprias e adequadas à particularidade brasileira. A concepção de Lênin é, por isso, uma espécie de fundo secreto da obra A revolução burguesa no Brasil. Ressaltando que Lênin (2012), já no início do século XX, distinguia o caso específico de alguns países da América Latina, como a Argentina, que, embora não fossem colônias e nem semicolônias, encontravam-se envolvidos nas malhas da dependência econômica e financeira.

O ensaio sobre a revolução burguesa no Brasil dialoga também com todo o chamado pensamento social brasileiro3. Trata-se de uma interpretação do Brasil - ou "imagem do Brasil" nos termos de Coutinho (2011) - que se conforma enquanto uma síntese superadora de duas concepções extremas: de um lado, aqueles que acreditavam que o capitalismo nunca se desenvolveu plenamente no Brasil (tais como Nelson Werneck Sodré e as formulações que predominaram no Partido Comunista Brasileiro (PCB) ao longo do século

\footnotetext{
${ }^{2}$ Quando Lênin (1980 apud COUTINHO, 2011, p. 204-205) analisa, por exemplo, o processo tardio da unificação alemã, caracterizando-o como via prussiana de desenvolvimento capitalista, a questão da propriedade da terra e da transformação das relações agrárias é central. O revolucionário russo constata que, diferente da via clássica, em que há uma radical transformação da estrutura agrária convertendo a antiga propriedade em pequena exploração camponesa, no caso da via prussiana a velha propriedade rural conserva sua concentração de terra e se torna empresa agrária capitalista, preservando formas pretéritas de coerção extra econômica sobre o trabalhador.

3 Este pensamento advém de uma cultura acadêmica que firmou uma certa tradição de grandes ensaios interpretativos do Brasil. Sendo marcantes obras como Raízes do Brasil e Caminhos e fronteiras, de Sérgio Buarque de Holanda; Formação do Brasil contemporâneo e A revolução brasileira, de Caio Prado Jr; Casa grande e senzala e Ordem e progresso, de Gilberto Freyre; Coronelismo, enxada e voto, de Victor Nunes Leal; Os donos do poder, de Raymundo Faoro; e Formação econômica do Brasil, de Celso Furtado.
}

Temporalis, Brasília (DF), ano 19, n. 37, p. 10-25, jan./jun. 2019. ISSN 2238-1856 
$\left.\mathrm{XX}^{4}\right)$, e, do outro lado, aqueles que afirmavam que o Brasil já era capitalista desde o século XVI em seu período escravista e colonial (tal como Caio Prado Jr.5).

Em suma, o sociólogo demonstra que a dependência econômica perpassou toda a história nacional desde a Colônia, contribuindo ao processo de acumulação primitiva précapitalista ${ }^{6}$ e posteriormente integrando-se de maneira subordinada à ascensão do modo de produção capitalista. Passamos de uma economia escravista mercantil, que perdurou na Colônia e no Brasil Império, para uma economia capitalista no período de transição para a República, com a generalização do trabalho assalariado. Esse processo foi desencadeado pela emergência de uma revolução burguesa atípica que teve como principais protagonistas as antigas oligarquias rurais que se aburguesaram e os comerciantes imigrantes. Essa revolução burguesa conforma um tipo de desenvolvimento capitalista que refuncionaliza e integra à sua própria dinâmica resquícios do passado colonial e escravista. Diferente do dualismo cepalino - cujo importante expoente é a obra de Celso Furtado (1959) - e sua crença de que o desenvolvimento nacional superaria os resquícios do passado, a concepção de Fernandes entende a inter-relação dialética entre o novo e o velho, num processo que o autor conceitua, inspirado em Moore Jr., como modernização conservador $a^{7}$. O fato de o capitalismo aqui modernizar-se não necessariamente significa a superação das estruturas e superestruturas arcaicas, pois estas são refuncionalizadas e integradas na dinâmica do desenvolvimento capitalista dependente.

O golpe civil-militar de 1964 evidenciou a impossibilidade de um desenvolvimento capitalista autônomo e cristalizou a dupla articulação dependência externa - segregação

\footnotetext{
${ }^{4}$ Nelson Werneck Sodré realizou importantes esforços no sentido de compreender o estado da arte da revisão histórica do Brasil. Suas principais limitações estavam na constatação da existência de feudalismo no Brasil e na compreensão dualista da relação entre o arcaico e o moderno, que o fazia acreditar na possibilidade de um desenvolvimento nacional modernizante autônomo apoiado em uma suposta burguesia nacional dotada de um sentimento nacional. As teses de Sodré tiveram importante influência na orientação do Partido Comunista Brasileiro (PCB) ao longo do século XX, e contribuíram na formulação da orientação política que vislumbrava uma etapa democrático-burguesa para a revolução brasileira que antecederia a etapa socialista (CONTE, 2010).

${ }^{5}$ Para Carlos Nelson Coutinho (2011): "[...] o estoque de categorias marxistas de que se vale Caio Prado não é muito rico [...]. Nos trabalhos de história, por exemplo, tem pouco peso o conceito de 'modo de produção', o que o leva por vezes a confundir, na análise da Colônia e do Império, o predomínio inequívoco de relações mercantis com a existência de um sistema capitalista (ainda que 'incompleto'), erro derivado da prioridade metodológica que ele conscientemente atribui à esfera da circulação em detrimento da esfera da produção. Isso faz também com que ele utilize de modo pouco rigoroso a noção de burguesia: seriam 'grandes burgueses nacionais', por exemplo, os latifundiários escravocratas do Império” (COUTINHO, 2011, p. 202-203). ${ }^{6} \mathrm{O}$ movimento da produção capitalista só poderia realizar-se pressupondo a existência de massas relativamente grandes de capital e de força de trabalho, generalizando o trabalho assalariado. Para Marx (2013) "[...] todo esse movimento parece [...] girar num círculo vicioso, do qual só podemos escapar supondo uma acumulação 'primitiva' [...] prévia à acumulação capitalista" (MARX, 2013, I, p. 785, grifos nossos), acumulação esta que "[...] não é resultado do modo de produção capitalista, mas seu ponto de partida" (MARX, 2013, I, p. 785, grifos nossos). A história da acumulação primitiva "[...] assume tonalidades distintas nos diversos países e percorre as várias fases em sucessão diversa e em diferentes épocas históricas" (MARX, 2013, I, p. 787-788).

7 Barrington Moore Junior (1975) emprega o conceito de modernização conservadora para caracterizar o caso específico de desenvolvimento capitalista na Alemanha e no Japão. Estes países realizaram revoluções burguesas vindas "de cima" através de um processo de modernização que se baseou na industrialização condicionada por um pacto político edificado entre a burguesia e os terra tenentes, conduzindo-os a regimes políticos autocráticos.
}

Temporalis, Brasília (DF), ano 19, n. 37, p. 10-25, jan./jun. 2019. ISSN 2238-1856 
interna que caracteriza o capitalismo dependente brasileiro ${ }^{8}$. Se no período colonial o excedente da produção escravista ia todo para a Metrópole e o senhor de engenho recebia da Coroa uma espécie de remuneração ${ }^{9}$, no período capitalista temos uma apropriação dual do excedente, em que a burguesia nativa se apropria de parte deste excedente e outra parte fica com a burguesia dos países centrais do imperialismo.

A submissão e dependência externa caracteriza a natureza heteronômica do capitalismo brasileiro. A consolidação do capitalismo monopolista e da autocracia burguesa no Estado integra plenamente o Brasil na estrutura hierárquica do imperialismo total hegemonizado pelos Estados Unidos ${ }^{10}$. Essa condição impede a conformação de uma superestrutura liberal-democrática de tipo clássico, realidade que se explicita se levamos em conta a sucessão de golpes de Estado e restrições democráticas que configuram a história política brasileira. O caráter tardio de nosso desenvolvimento capitalista também faz com que a burguesia emergente prefira se aliar às antigas classes dominantes e excluir qualquer possibilidade de um compromisso permanente com os 'de baixo'. Isso ocorre porque nossa burguesia se incorpora ao sistema de poder imperialista mundial num período em que já se dá uma batalha de vida ou morte entre capitalismo e socialismo, radicalizando o caráter reacionário das burguesias imperialistas e das burguesias dependentes. A classe dominante brasileira enfrenta essa realidade através da contrarrevolução prolongada que combina formas mais ou menos explícitas de poder autocrático.

\section{DISTENSIONAMENTO DA CONTRARREVOLUÇÃO E DEMOCRACIA DE COOPTAÇÃO}

Na parte final do ensaio A Revolução Burguesa no Brasil, Florestan Fernandes (2005) indica as possibilidades que poderiam decorrer de um distensionamento da contrarrevolução preventiva, afirmando que a autocracia burguesa poderia levar "[...] à uma democracia restrita típica, que também pode ser designada como democracia de cooptação" (FERNANDES, 2005, p. 416). O processo de cooptação busca estender as fronteiras da consciência burguesa dentro das classes trabalhadoras e dos setores marginalizados da população. Mas as convulsões próprias da sociedade de classes geram necessariamente miséria, desorganização social, desenraizamento cultural, ocasionando lutas e protestos

\footnotetext{
${ }^{8}$ Paulo Netto (2014) demonstra como os anseios de superação da dependência e ampliação da democracia exacerbados no governo Jango não significaram que o país vivia propriamente um período revolucionário. A ordem capitalista não estava imediatamente ameaçada, mas o modelo autocrático dependente do desenvolvimento capitalista brasileiro de alguma maneira começava a ser colocado em xeque. Para o autor o golpe significou principalmente a liquidação de qualquer possibilidade de reverter a dependência, significou a plena vinculação da economia brasileira aos interesses imperialistas e o coroamento da impossibilidade de democratizar substantivamente a sociedade brasileira.

9 O que ficava nas mãos do produtor colonial, segundo Fernandes (2005), “[...] não era um excedente gerado por esta forma de capitalização [...]”, mas sim “[...] uma espécie de remuneração [....]”, uma parcela da apropriação colonial, aquilo "[...]que restava e não fora absorvido pela Coroa e pelas agências comerciais" (FERNANDES, 2005, p. 41-42).

${ }^{10}$ Florestan Fernandes (2005) considera que sob o capitalismo monopolista o imperialismo torna-se um imperialismo total, que não conhece fronteiras e não tem freios, penetrando nos países periféricos ${ }^{10}$ a partir de dentro, "[...] enquistando-se nas economias, nas culturas e nas sociedades hospedeiras" (FERNANDES, 2005, p. 320). Enquanto o antigo imperialismo constituía uma manifestação de concorrência nacional entre economias capitalistas avançadas, o novo imperialismo representa uma luta violenta pela sobrevivência e pela supremacia do capitalismo em si mesmo. Algumas características centrais desse domínio seriam: "[...] a expansão incoercível da empresa corporativa, a hiperinfluência das finanças internacionais e a hegemonia dos Estados Unidos" (FERNANDES, 2009, p. 30).
}

Temporalis, Brasília (DF), ano 19, n. 37, p. 10-25, jan./jun. 2019. ISSN 2238-1856 
que se chocam com a ordem. Decorrem, então, “[...] tanto movimentos de protesto dentro da ordem corrompidos pelo sistema, quanto protestos contra a ordem de caráter revolucionário" (FERNANDES, 2005, p. 422-423).

As classes dominantes brasileiras, mesmo que possam impulsionar um distensionamento do regime ditatorial, não podem abrir mão,

[...] das próprias vantagens e privilégios; dos controles de que dispõem sobre si mesmas, como e enquanto classes; e dos controles de que dispõem sobre as classes operárias, as massas populares e as bases nacionais das estruturas de poder. As vantagens e privilégios estão na raiz de tudo, pois se as classes burguesas realmente "abrissem" a ordem econômica, social e política, perderiam, de uma vez, qualquer possibilidade de manter o capitalismo e preservar a íntima associação existente entre dominação burguesa e monopolização do poder estatal pelos estratos hegemônicos da burguesia (FERNANDES, 2005, p. 422).

Deste modo, a democracia de cooptação possui pouca eficácia e pouca flexibilidade em nações capitalistas pobres onde a extrema concentração da riqueza e do poder deixa para as classes dominantes "[...] um escasso excedente para dividir na compra de alianças ou de lealdades" (FERNANDES, 2005, p. 424). A cooptação acaba concorrendo para "[...] exacerbar as contradições intrínsecas ao regime de classes, levando-as a pontos explosivos de efervescência, que mais debilitam que fortalecem o Estado autocrático [...]" (FERNANDES, 2005, p. 424), e o mesmo é compelido "[...] a funcionar sob extrema tensão permanente e autodestrutiva, de insuperável paz armada" (FERNANDES, 2005, p. 424). Essas tendências apontadas já nos trazem um eixo para analisar o que foi a transição que colocou fim à ditadura aberta de classe, enquanto um processo de distensionamento que mesclou uma reciclagem da autocracia com a democracia de cooptação ${ }^{11}$.

O autor expõe alguns elementos que antecipam o que futuramente ocorreu na transição pós-ditadura, no sentido de que já haviam alguns tímidos esforços de uma distensão política que traria um avanço democrático que "apenas repõe o problema político da hegemonia burguesa" no sentido de "[...] criar os vínculos orgânicos que deverão entrelaçar os mecanismos da democracia de cooptação com a organização e o funcionamento do Estado autocrático" (FERNANDES, 2005, p. 421, grifos nossos). A abertura em curso, deste modo, não leva à uma democracia burguesa, mas à consolidação da autocracia burguesa. Ela amplia e consolida a democracia de cooptação, abrindo-a para baixo e para a dissidência esterilizada e esterilizável. Isso faz com que o Estado autocrático "[...] defina constitucional e legalmente o alcance de seu poder legítimo excedente" (FERNANDES, 2005, p. 421).

A burguesia monopolista lida com as possibilidades oferecidas pelo golpismo ou pela democracia de cooptação de acordo com as necessidades de cada conjuntura. Seu próprio caráter dependente faz a corrupção e a cooptação material de camadas médias e baixas da população algo bastante restrito e pouco flexível, que pode inclusive se restringir ainda mais nos momentos de crise. Torna-se também necessário, portanto, a cooptação ideológica, a introjeção da consciência burguesa nas classes trabalhadoras, apresentando os interesses particulares da classe dominante como se fossem interesses universais de toda sociedade. Essa constatação da cooptação e da extensão da consciência das classes

\footnotetext{
${ }^{11}$ Embora afirme que a democracia de cooptação possui pouca flexibilidade para uma classe dominante com muito pouco a ceder, em nenhum momento Florestan Fernandes a descarta como possibilidade.
} 
dominantes para os setores populares, como bem ressalta Coutinho (2011), vai no sentido do que Antônio Gramsci categorizou como transformismo.

Da mesma maneira que nossa Independência não resultou de uma ruptura política e de uma guerra de libertação, o distensionamento da ditadura civil-militar também se deu da forma "menos perigosa possível" para as classes dominantes e seus representantes políticos. A anistia "ampla, geral e irrestrita" não desmantelou o aparelho militar do regime arbitrário, que segue vigente ameaçando qualquer aprofundamento de uma democracia para as massas. Podemos afirmar que, se "[...] não tivemos a ditadura mais sangrenta e aguerrida, coube-nos a que ficou mais enquistada nos organismos do Estado e no aparelho do governo" (FERNANDES, 1986, p. 22).

O afastamento dos militares do governo e a instituição de um presidente civil sem dúvida significou uma derrota para a ditadura, mas tratou-se de uma derrota que se caracterizou pela sua autopreservação. Com o movimento das Diretas as forças conservadoras descobriram "[...] que a inquietação social campeava mais solta e mais forte que em 1964 [...]" (FERNANDES, 1986, p. 22) e avançaram "[...] no sentido de uma composição pelo alto, respeitando o seu braço armado" (FERNANDES, 1986, p. 22). As massas populares, apesar de lograrem algumas vitórias, acabam sendo levadas a reboque por essas forças da ordem, pois "[...] apesar da miséria, da inquietação social e do desemprego" (FERNANDES, 1986, p. 23), elas "[...] ainda não encontraram os meios de luta política organizada mais eficientes para os seus propósitos" (FERNANDES, 1986, p. 23), e acabam ficando "[...] à mercê de envolvimentos que fortalecem os seus adversários e mantém o status quo ante com pequenas modificações" (FERNANDES, 1986, p. 23).

No entanto, o autor não despreza a importância que a luta dos setores populares teve na derrota da ditadura, para ele a "[...] desagregação do sistema ditatorial não se deu de cima para baixo, ela se deu de baixo para cima através das lutas de classes dos trabalhadores e também de várias camadas da população, principalmente dos setores mais pobres e mais oprimidos" (FERNANDES, 1994, p. 121, grifos nossos). Dessa maneira as "[...] fendas da ditadura vieram de baixo e muitas das contradições que a burguesia enfrenta hoje resultam da insatisfação acumulada ao longo de vinte e um anos de desmandos, desbaratamento dos recursos públicos e de incompetência" (FERNANDES, 1994, p. 121).

Nesse contexto a conciliação bane a reforma e no seu lugar ocorre uma modernização controlada a partir de fora e a partir de cima. A grande burguesia nativa opera como correia de transmissão do desenvolvimento (técnico, científico, político, etc.) dirigido a partir de fora. Somente é instrumental para tais mudanças aquilo que não perturba a ordem, que extrai do desenvolvimento capitalista o máximo de vantagens para o capital privado nacional e estrangeiro. É assim que a conciliação se correlaciona com o desenvolvimento capitalista de tal modo que "[...] incentiva as classes dirigentes a bloquear as reformas e as revoluções típicas do capitalismo para assegurar ao desenvolvimento capitalista e à acumulação capitalista o máximo possível de aceleração crescente" (FERNANDES, 1986, p. 68).

A transição pós-ditadura demonstrou “[...] o avanço do movimento burguês na direção de uma autopreservação [...]" (FERNANDES, 1994, p. 121), que foi possível “[...] por causa da convergência dos vários grupos (o sistema militar com sua vanguarda político-militar, os

Temporalis, Brasília (DF), ano 19, n. 37, p. 10-25, jan./jun. 2019. ISSN 2238-1856 
setores conservadores do PMDB, o PDS, os chamados liberais que romperam com o PDS) [...]" (FERNANDES, 1994, p. 121), e estes conformaram a "[...] base política para uma transição conservadora" (FERNANDES, 1994, p. 121) . No entanto, "[...] esta base não encontrou o equacionamento político das soluções que a Nação estava exigindo [...]" (FERNANDES, 1994, p. 121), demonstrando dificuldades que inquietaram a burguesia: "Ela, perdendo o regime ditatorial, perdeu a capacidade de dispor do arbítrio [...]" (FERNANDES, 1994, p. 122) e se viu "[...] obrigada a absorver os golpes que vinham de várias direções, inclusive de setores de classe média e da pequena burguesia que foram duramente castigados pela política econômica, desemprego, etc." (FERNANDES, 1994, p. 122).

Tratando do processo constituinte, Luiz Carlos Prestes (1987 apud PRESTES, A., 2018, p. 89) questionava o teor democrático de uma transição que conciliava com o passado sem uma ruptura com o poder autocrático:

O Brasil está, depois de 21 anos de uma ditadura militar, com um governo civil. Chamam a isso Nova República. Mas [...] nenhum general fascista foi afastado, os assassinos que torturavam, matavam presos políticos não foram punidos. Nenhum deles. [...] A legislação fascista continua toda de pé. Lei de Segurança Nacional, lei contra as greves, lei contra os estrangeiros, tudo isso continua da mesma forma, não houve modificação. [...] A tal República Nova já nasceu velha. Porque, em vez de uma solução radical, que o povo desejava, o que tivemos foi uma conciliação geral (PRESTES, L., 1987 apud PRESTES, A., 2018, p. 8-9).

A eleição da Constituinte se deu, para Prestes (1987 apud PRESTES, A., 2018), sem que nenhuma lei dos generais fosse revogada. Nessas condições, ela não teria como ser soberana e livre. A interferência do poder econômico foi determinante na eleição dos Deputados, tratando-se de "[...] uma Constituinte dos grandes empresários, que haviam financiado a eleição" (PRESTES, L., 1987 apud PRESTES A., 2018). Apesar de que "A minoria, mais radical, tem homens honestos, homens sérios, [...] como Florestan Fernandes, por exemplo [...]. Mas não passam de quarenta, em uma Constituinte de 550. Então, o que eles podem fazer?" (PRESTES, L., 1987 apud PRESTES, A., 2018, p. 9).

Após o afastamento dos militares do governo (mas não do poder do Estado) foi possível observar a impotência ${ }^{12}$ da burguesia brasileira em lidar por si mesma com os problemas do País. Essa burguesia " [...] se alia ao grande capital estrangeiro e fica sem meios materiais para resolver as grandes questões nacionais [...]" (FERNANDES, 1994, p. 127), todo o “[...] excedente econômico é drenado para o exterior, não só na forma de juros da dívida, mas também através de outros mecanismos" (FERNANDES, 1994, p. 127). Esse modelo de transição que foi construído sob o regime de Geisel e Figueiredo, consiste na transição lenta, gradual e segura para o grande capital, para os interesses conservadores, para a intransigente defesa da ordem estabelecida. O centro do poder está no que Fernandes (1994) chama de "dispositivo militar", e o presidente Sarney cumpriu o papel de servir de fachada para o regime.

O dispositivo ou "tutela militar" segue perdurando como obscuro poder colocado acima das possibilidades de incisão democrática no Estado ${ }^{13}$. No período da promulgação da Constituição de 1988, Luiz Carlos Prestes ainda retomaria em 1988 a abordagem de sua tese

\footnotetext{
${ }^{12} \mathrm{O}$ que não significa aqui debilidade no sentido da defesa e manutenção do seu poder.

${ }^{13}$ Perceba-se que não estamos afirmando que tais incisões democráticas não sejam possíveis ou viáveis, mas sim que a tutela militar segue pairando obscuramente sobre elas.
}

Temporalis, Brasília (DF), ano 19, n. 37, p. 10-25, jan./jun. 2019. ISSN 2238-1856 
sobre o poder militar, constatando que "[...] todos os que se têm manifestado para exaltar o trabalho realizado pelos senhores constituintes e, muito particularmente, eles próprios, muito significativamente silenciam a respeito do artigo 142, que se refere às Forças Armadas" (PRESTES, L., 1988 apud PRESTES, A., 2018, p. 9). Prestes ressalta que nesse artigo são atribuídas aos militares "[...] funções evidentemente incompatíveis com um regime efetivamente democrático" (PRESTES, L., 1988 apud PRESTES, A., 2018, p. 9). O artigo concede às Forças Armadas a atribuição de garantirem a lei e a ordem, atribuição que, segundo Prestes, "[...] nem ao presidente da República ou aos outros dois poderes do Estado é tão expressamente concedida” (PRESTES, L., 1988 apud PRESTES, A., 2018 p. 9). Para o comunista brasileiro, o artigo 142 contraria "[...] conhecido preceito da tradição constitucional de nosso país, que sempre afirmou serem os três poderes do Estado autônomos, mas harmônicos entre si, não podendo, portanto, nenhum deles tomar qualquer iniciativa isoladamente" (PRESTES, L., 1988 apud PRESTES, A., 2018, p. 9-10).

Abordando a essência do artigo 142, Luiz Carlos Prestes (1988 apud PRESTES, A., 2018, p. 10) ainda afirmaria:

Em nome da salvaguarda da lei e da ordem pública, ou de sua "garantia”, estarão as Forças Armadas colocadas acima dos três poderes do Estado. Com a nova Constituição, prosseguirá, assim, o predomínio das Forças Armadas na direção política da Nação, podendo, constitucionalmente, tanto depor o presidente da República quanto os três poderes do Estado, como também intervir no movimento sindical, destituindo seus dirigentes ou intervindo abertamente em qualquer movimento grevista, como vem se fazendo desde os decretos de Getúlio Vargas de 1931, ou mesmo, voltando aos tempos anteriores, em que a questão social era considerada uma questão de polícia, segundo o senhor Washington Luís.

A respeito da formação da Assembleia Nacional Constituinte que resultou na aprovação da atual Constituição Cidadã de 1988, Florestan Fernandes ressalta que a "[...] pressão popular do movimento das diretas-já e das greves operárias alterou a qualidade do processo político brasileiro, mostrando que a oposição é forte e poderia chegar à insurreição [...]" (FERNANDES, 1994, p. 127-128), o que foi percebido pelos conservadores que buscaram uma maneira de manipular e conduzir o movimento popular para reestabelecer o equilíbrio. Verificou-se a continuidade de uma tradição brasileira de manipulação "[...] que, nesses momentos, sempre conjuga conciliação e reforma [...]", mas a reforma nunca é adotada, "[...] é sempre conciliação conservadora" (FERNANDES, 1994, p. 128). Os donos do poder fazem algumas concessões "[...] e, assim, respiram e seguram as rédeas do poder" (FERNANDES, 1994, p. 128).

Expondo conclusões extraídas da sua própria experiência como Deputado Constituinte, Fernandes (1994) explica que mesmo que "[...] a esquerda esteja presente e obtenha algumas conquistas visíveis na Constituição, estas conquistas perdem o caráter proletáriosocialista [...]" (FERNANDES, 1994, p. 157), e nem sequer “[...] ganham o sentido de reformas estruturais burguesas, propriamente ditas, pois resultam sempre de acordo, da conciliação" (FERNANDES, 1994, p. 157). A Constituição de 1988:

É nitidamente uma Constituição melhor, com uma ampliação da temática, com uma redefinição das liberdades fundamentais, dos direitos sociais, mas tudo isso são conquistas no terreno abstrato. Veja que os trabalhadores, os aposentados, precisam recorrer à Justiça para descobrir se certas disposições constitucionais são 
aplicáveis ou não e para conseguir impô-las, nem sempre com êxito! (FERNANDES, 1994, p. 158).

Carlos Nelson Coutinho defende que esta compreensão de que a burguesia brasileira não seria capaz de renunciar a estruturas autocráticas de dominação estaria na raiz dos erros do ‘último Florestan'. O autor admite que “[...] Florestan desmistificou muitas das ilusões que dominavam setores importantes da esquerda em sua avaliação da situação aberta com a chamada "Nova República' [...]" e "[...] muito daquilo que a alguns de nós parecia na época manifestação do 'sectarismo' do velho Florestan era, ao contrário, a confirmação da sua lucidez analítica e da sua capacidade de previsão" (COUTINHO, 2011, p. 238). Porém, o filósofo considera que Florestan não soube captar o conjunto do processo de abertura e não deu devida importância às pressões e conquistas das classes subalternas, pois, mesmo que a transição "[...] em seu momento resolutivo, tenha reproduzido a velha tradição brasileira dos 'arranjos' pelo alto - foi também determinada, pelo menos em parte, pelas pressões que provinham 'de baixo"' (COUTINHO, 2011, p. 234).

Em nome da dicotomia entre a proposta de revolução 'processual' de um lado e a proposta de revolução 'explosiva' de outro, Coutinho (2011) considera que os termos trabalhados por Florestan para designar o distensionamento da ditadura civil-militar (tais como transação conservadora, transição pelo alto, democracia de cooptação) não dariam a devida importância às possibilidades democráticas vislumbradas pelo filósofo a partir da 'Nova República' e da Constituição de 1988 (COUTINHO, 2011).

Ora, como já demonstramos aqui, Fernandes (1986; 1994) não nega a força que o movimento popular teve na luta pelas Diretas Já e nem as conquistas formais no sentido dos direitos sociais e das liberdades fundamentais com a nova Constituição. $\mathrm{O}$ que o sociólogo de fato não faz é nutrir grandes expectativas de que somente pela via institucional estariam assegurados os direitos sociais e a possibilidade de se avançar na superação da dependência e na construção do socialismo. Para Florestan, não se trata de contrapor, como pretende Coutinho (2011), uma ideia de revolução 'explosiva' contra uma ideia de revolução 'processual' ou vice-versa, mas de compreender o entrelaçamento dialético inevitável entre reforma e revolução ${ }^{14}$, isto é, a interrelação entre revolução dentro da ordem e revolução contra a ordem ${ }^{15}$. Diferente da perspectiva de Coutinho (1984), que nos anos 1980 tratava a 'democracia como valor universal', Florestan Fernandes (1980) entendia que existe necessariamente uma ruptura entre a democracia burguesa e a democracia proletária e popular (FERNANDES, 1980).

Nada na história contemporânea pode nos levar a decretar o fim de qualquer ruptura, de qualquer salto de qualidade ou descontinuidade dialética. Temos inclusive diversos exemplos atuais de ruptura institucional promovidas pelas próprias classes dominantes. A processualidade e o acúmulo de forças através da conquista de reformas estruturais ainda dentro da ordem não nega a possibilidade ou a necessidade de rupturas e transformações para além da ordem, pelo contrário, são o resultado necessário deste movimento

\footnotetext{
${ }^{14}$ Para a crítica da ideia de que é possível transitar do capitalismo ao socialismo sem ruptura ver a polêmica de Lênin (2010) com Kautsky no texto O Estado e a Revolução, publicado originalmente em 1917.

${ }^{15}$ Segundo Fernandes (1980) a multiplicidades de escolhas, de vias e de caminhos revitaliza "[...] tanto o socialismo reformista e gradualista, quanto o socialismo revolucionário [...]" (FERNANDES, 1980, p. 23), mostrando "[...] que não existe só uma via para se chegar ao socialismo e que há campo para a atividade construtiva da revolução proletária nas diferentes nações, nos diferentes continentes" (FERNANDES, 1980, p. 23).
} 


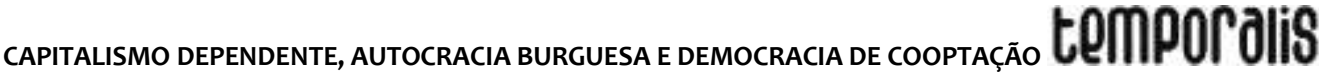

contraditório, que pode pender para a revolução protagonizada pelas classes trabalhadoras ou para a contrarrevolução protagonizada pelo poder burguês.

\section{GOLPE DE ESTADO DE 2016: O FARDO HISTÓRICO NOVAMENTE SE IMPÕE}

O golpe de Estado de 2016, em nossa avaliação, confirma a posição de Fernandes (2005) sobre a pouca flexibilidade da democracia de cooptação e a manutenção de um domínio autocrático no Estado por parte da burguesia brasileira. Trata-se de mais uma demonstração do poder e da atuação extra institucional das classes dominantes brasileiras. O processo arbitrário que destituiu a presidente legitimamente eleita Dilma Rousseff foi notoriamente uma surpresa para toda uma geração que se formou acreditando que os preceitos democráticos de nossa última Constituição perdurariam plenamente como conquista irreversível. Na opinião de Luis Felipe Miguel:

\footnotetext{
Essa é a armadilha da democracia limitada que temos: incentiva que a luta política seja sempre canalizada para as eleições. Mas se há algo que os últimos acontecimentos deixam claro é que não há transformação possível sem investimento na luta extrainstitucional. O Estado capitalista não é neutro, nem sua lei, nem seus aparelhos. A pressão pela mudança pode até ingressar nele, introduzindo contradições, mas só tem condições de triunfar se estiver fortemente ancorada do lado de fora (MIGUEL, 2016, p. 32).
}

Estamos diante de mais uma comprovação histórica de que o poder extrainstitucional das classes dominantes brasileiras age arbitrariamente quando considera imprescindível tal operação. Numa conjuntura de crise, a burguesia pró-imperialista passa a não tolerar inclusive governos "conciliadores" que não implementem medidas antinacionais e antipopulares na forma e no ritmo necessários.

O golpe de 2016 marca uma fratura irremediável no experimento democrático iniciado no Brasil em 1985. Ainda que com limitações e contradições, a ordem balizada pela Constituição de 1988 garantia a vigência das instituições mínimas da democracia liberal: o voto popular como meio necessário para a obtenção do poder político e o império da lei. A derrubada da presidente Dilma, mediante um processo ilegal, sinalizou que tais institutos deixaram de operar e, por consequência, o sistema político em vigor no país não pode mais receber o título de 'democracia' - mesmo na compreensão menos exigente da palavra. (MIGUEL, 2016, p. 29).

A realidade não estaria comprovando justamente a posição de Fernandes (2005) quando fala da pouca flexibilidade da democracia de cooptação numa realidade em que a burguesia tem muito pouco a ceder? Nas palavras de Miguel (2016, p. 30) a tolerância das classes dominantes brasileiras em relação à democracia formal "[...] parece ir muito pouco além da concessão do sufrágio universal. O povo até pode votar, mas que os tomadores de decisão levem em conta minimamente os interesses das classes populares já é motivo para escândalo" (MIGUEL, 2016, p. 30). O aparelho do Estado é programado, deste modo, para resistir a mudanças conjunturais "[...] deslocando o poder de veto de um de seus componentes para outro - por exemplo, do Executivo para o Legislativo, de uma casa do Congresso para outra, depois para o Judiciário, enfim para as Forças Armadas -, conforme necessário" (MIGUEL, 2016 p. 31). O próprio poder judiciário atua “[...] na solução de uma contradição aparentemente insuperável entre o modelo do Estado Democrático de Direito erigido em 1988 e uma tradição autoritária que se soma a uma legislação liberal- 
conservadora que se seguiu à Carta" (SEMER, 2016, p. 92, grifo nosso). Os ritos democráticos, por isso, "[...] só vigoram dentro de limites estreitos, vinculados à permanência de uma sociedade altamente hierarquizada e desigual e de nossa posição periférica na divisão mundial do trabalho" (MIGUEL, 2016 p. 32-33).

Abordando a história mundial nos últimos dois séculos, Michael Lowy considera que:

[...] o que predomina é o Estado de exceção. A democracia é que foi excepcional. De uma forma ou de outra, fica claro que ela é um peso grande para o Estado, para as classes dominantes e para o capital financeiro. A democracia atrapalha, ela não facilita o trabalho da política capitalista. Daí a tendência a reduzir o espaço democrático, tomar medidas de exceção e até mesmo usar o método do golpe, como estamos vendo na América Latina. O golpe de 2016 no Brasil não é o primeiro. Já tivemos golpes em Honduras e no Paraguai (LOWY, 2016, p. 55).

Na América Latina são diversos os exemplos de tentativas da burguesia oligárquica de restabelecer seu poder tradicional, com distintos tipos de golpes apoiados pelo imperialismo estadunidense. Em casos como na Venezuela, Bolívia e Equador "[...] essas tentativas fracassaram, graças a uma ampla mobilização popular antigolpista [...]" (LOWY, 2016, p. 56), no entanto, em 2009 o presidente democraticamente eleito de Honduras, Manuel Zelaya "[...] que tentou realizar algumas modestas reformas, foi derrubado com uma intervenção pseudolegal da Corte Suprema, com o apoio do Exército" (LOWY, 2016, p. 56). No Paraguai em 2012 o presidente Lugo é deposto pelo Senado, acusado em 2012 de apoiar movimentos camponeses: "Governos direitistas e autoritários substituíram os dirigentes progressistas em ambos os países, com o apoio do imperialismo americano" (LOWY, 2016, p. 56).

No Brasil, na análise de Anita Leocádia Prestes (2018), permanece a tutela militar sobre o Estado:

Hoje, o artigo 142 da Constituição de 1988 continua vigente, o que reforça a tese defendida por Prestes do poder militar e de sua tutela sobre a nação. Recentemente, em 24/5/2017, o presidente Michel Temer recorreu a esse artigo da Constituição (regulamentado pela lei complementar n 97 de 1999 e pelo decreto presidencial 3.897 de 2001) 'para garantir a segurança no Distrito Federal', com o objetivo de enfrentar as manifestações populares que estavam em curso na capital da República (PRESTES, A., 2018, p. 11).

Anita Prestes conclui reafirmando que trinta anos após a promulgação da Constituição de 1988 “[...] permanecemos reféns da tutela militar, com o artigo 142 da Constituição em plena vigência, voltando inclusive a ser utilizado contra a manifestação popular, e a Lei de Segurança Nacional sendo mantida como uma espada de Dâmocles sobre a cabeça de todos os brasileiros" (PRESTES, A., 2018, p. 14). Vivemos em uma democracia que se aproxima de um regime de exceção: “[...] tutela militar sobre os poderes da República, permanência da Lei de Segurança Nacional, Lei da Anistia garantidora da impunidade dos torturadores - de uma maneira geral, manutenção do arcabouço jurídico da Doutrina de Segurança Nacional” (PRESTES, A., 2018, p. 14).

A pressão popular pode impor e arrancar mudanças que atenuam o nível de hostilidade da autocracia burguesa, mas a autocracia se recompõe cedendo apenas em questões que não ameaçam a continuidade da reprodução do seu poder. Considerar este fato não significa 


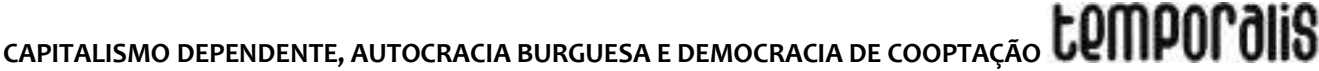

descartar a importância das conquistas logradas pelo movimento popular, mas encarar com realismo os limites de tais conquistas no âmbito de um contexto em que a manutenção da ordem capitalista dependente busca mecanismos de reciclagem do poder autocrático.

\section{CONCLUSÃO}

Com base na pesquisa realizada, concluímos que o eixo de análise legado por Fernandes tratando da relação entre o aprofundamento da dependência, a manutenção da autocracia burguesa e a democracia de cooptação possui plena validade quando consideramos os fatos históricos recentes. O processo constituinte que resultou na Constituição de 1988 sem dúvida trouxe avanços institucionais em direitos sociais e democráticos que foram resultado da pressão popular, mas, ao mesmo tempo, manteve-se a tutela militar sobre o Estado, expressa no artigo 142 da Constituição.

Fernandes $(1986 ; 1994)$ não nega a força que o movimento popular teve na luta pelas Diretas Já e nem as conquistas formais no sentido dos direitos sociais e das liberdades fundamentais com a nova Constituição, mas não considera que somente pela via institucional estariam assegurados os direitos sociais e a possibilidade de superação do modelo capitalista dependente. A articulação extra institucional das classes dominantes evidencia que o contraponto da luta popular também precisa se dar, conjuntamente com a disputa institucional, para além das instituições.

O golpe de Estado de 2016 confirma a posição de Florestan sobre a pouca flexibilidade da democracia de cooptação e a manutenção de um domínio autocrático no Estado por parte da burguesia brasileira. As transformações contemporâneas exigem novas elaborações a respeito de questões como o domínio do capital financeiro, a captura da subjetividade e a potencialização da manipulação no capitalismo contemporâneo, as novas expressões do conservadorismo e do neofascismo na sociedade brasileira, as metamorfoses no mundo do trabalho, na legislação trabalhista e na relação Estado e sociedade civil, dentre outras. Mas, no que tange à caracterização histórica e estrutural da realidade socioeconômica do Brasil, concordamos com José Paulo Netto (2013) quando afirma que as questões centrais foram as colocadas por Florestan Fernandes.

No que diz respeito aos dilemas postos no enfrentamento da ordem vigente, acreditamos que os desafios colocados para as classes trabalhadoras e as esquerdas no Brasil são ao mesmo tempo desafios teóricos, políticos, práticos e organizativos. Nosso déficit não é apenas organizacional, pois quando faltam mediações capazes de impulsionar a mobilização e elevar o nível de consciência e organização popular, acreditamos que também nos falta uma apreensão teórica e uma direção ideológica capaz de elucidar a necessidade dessas mediações.

O imenso desafio que enfrentamos para a unidade dos movimentos e partidos que expressem as forças proletárias e populares em um projeto comum decorre também de uma espécie de corporativismo incapaz de vislumbrar as potencialidades do movimento e do desprendimento por uma unidade superior. De acordo com Fernandes (1980):

Quando se dá prioridade ao movimento socialista, estamos com isso debilitando os partidos socialistas? É claro que não! Desde que surja um espaço político

Temporalis, Brasília (DF), ano 19, n. 37, p. 10-25, jan./jun. 2019. ISSN 2238-1856 
comum e que ele seja respeitado e possa crescer - é claro que cada partido socialista pode explorar este espaço de uma forma crescente em termos de sua viabilidade, de sua variabilidade e de sua versatilidade. É claro que esse espaço, ao crescer, aumenta a liberdade dos partidos socialistas se realizarem; ele não limita essa liberdade, ele não a constrange. Aliás, o espaço comum não tem um fim específico, não se destina a alimentar o fluxo de desenvolvimento de uns partidos socialistas e a sufocar o de outros. De modo que o movimento não pode ser visto como uma arapuca; ele não nasce para destruir o socialismo, ao contrário, ele surge e vigora como fator de vitalidade, de versatilidade e de flexibilidade dos partidos (FERNANDES, 1980, p. 69-70).

O desprendimento e a capacidade de colocar na balança as convergências e as divergências para produzir novas sínteses que permitam uma unidade superior, não debilita o papel específico dos partidos e das organizações políticas. Pelo contrário, permite um raio de abrangência maior para suas políticas e a condução de uma disputa saudável que permita que as referências sejam erigidas com legitimidade do movimento geral, e não se autoproclamando através de processos corporativistas e arbitrários.

As lutas devem partir das necessidades mais sentidas, das reivindicações imediatas, e é no decorrer dos enfrentamentos que se torna possível elevar o nível de consciência e organização do povo a partir de instrumentos políticos coletivos capazes de fazer essa mediação. Eis o desafio histórico iminente no qual nos defrontamos, desafio que exige desprendimento e capacidade de aprender com os erros e acertos do passado e de absorver sem dogmatismo as contribuições filosóficas, científicas e políticas acumuladas até então. É necessário realismo para desvendar os fenômenos atuais e enfrentar com ousadia e consequência as barreiras do passado e do presente.

\section{REFERÊNCIAS}

ASSOCIAÇÃO BRASILEIRA DE ENSINO E PESQUISA EM SERVIÇO SOCIAL. Diretrizes gerais para o curso de Serviço Social. Rio de Janeiro, 1996.

COUTINHO, Carlos Nelson. Cultura e sociedade no Brasil: ensaio sobre ideias e formas. São Paulo: Expressão Popular, 2011.

COUTINHO, Carlos Nelson. A democracia como valor universal. Rio de janeiro: Salamandra, 1984.

CONTE, Daniela. Nelson Werneck Sodré e as interpretações do Brasil moderno (19581964): análise de conceitos e contexto de um intelectual brasileiro. 2010. Dissertação (Mestrado em História)- Programa de Pós-Graduação em História do Instituto de Filosofia e Ciências Humanas da Universidade Federal do Rio Grande do Sul, Porto Alegre, 2010.

FERNANDES, Florestan. A revolução burguesa no Brasil: ensaio de interpretação sociológica. 5. ed. São Paulo: Globo, 2005.

FERNANDES, Florestan. Nova República? Rio de Janeiro: Zahar, 1986.

FERNANDES, Florestan. Capitalismo dependente e classes sociais na América latina. São Paulo: Global, 2009. 


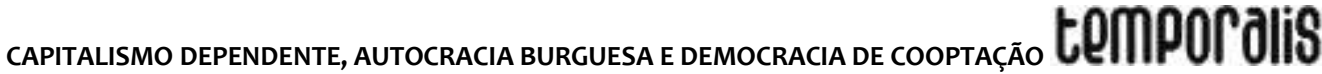

FERNANDES, Florestan. Democracia e desenvolvimento: A transformação da Periferia e o Capitalismo Monopolista da Era Atual. São Paulo: Hucitec, 1994.

FERNANDES, Florestan. Movimento socialista e partidos. São Paulo: Hucitec, 1980.

FURTADO, Celso. Formação Econômica do Brasil. Rio de Janeiro: Fundo de Cultura, 1959.

JINKINGS, I; DORIA, K; CLETO, M. (Orgs.). Porque gritamos golpe? São Paulo: Boitempo, 2016.

LÊNIN. V. I. Imperialismo, estágio superior do capitalismo: ensaio popular. São Paulo: Expressão Popular, 2012.

LENIN. V. I. O Estado e a Revolução. São Paulo: Expressão Popular, 2010.

LÊNIN. V. I. O desenvolvimento do capitalismo na Rússia: o processo de formação do mercado interno para a grande indústria. São Paulo: Nova Cultural, 1988.

LOWY, Michael. Da tragédia à farsa: o golpe de 2016 no Brasil. In: JINKINGS, I; DORIA, K; CLETO, M. (Orgs.). Porque gritamos golpe? São Paulo: Boitempo, 2016.

MARX, Karl. O Capital: crítica da economia política. Livro I: o processo de produção do capital. São Paulo: Boitempo, 2013.

MIGUEL, Luis Felipe. A democracia na encruzilhada. In: JINKINGS, I; DORIA, K; CLETO, M; (Orgs.). Porque gritamos golpe? São Paulo: Boitempo, 2016.

MOORE JUNIOR, B. As origens sociais da ditadura e da democracia: senhores e camponeses na construção do mundo moderno. São Paulo: Martins Fontes, 1975.

NETTO, J. P. A atualidade de Florestan Fernandes. Brasil de Fato, 2013. Disponível em: http://www.brasildefato.com.br/node/12398. Acesso em: 10 ago. 2018.

NETTO, J. P. Pequena história da ditadura brasileira (1964-1985). São Paulo: Cortez, 2014.

PRESTES, Anita Leocádia. Luiz Carlos Prestes, a Constituinte e a Constituição de 1988.

Revista Virtual EN_FIL - Encontros com a filosofia, v. 9, p. 1-14, 2018.

SEMER, Marcelo. Ruptura institucional e desconstrução do modelo democrático: o papel do judiciário. In: JINKINGS, I. DORIA, K. CLETO, M. (Orgs.). Porque gritamos golpe? São Paulo: Boitempo, 2016.

SOUZA, Antonio Candido de Mello e. Florestan Fernandes. São Paulo: Editora Fundação Perseu Abramo, 2001. 


\section{Davi Machado Perez}

Doutor em Serviço Social pela Universidade Federal de Santa Catarina - UFSC. Mestre e Bacharel em Serviço Social pela mesma instituição. Docente do Magistério Superior no Colegiado de Serviço Social da Universidade Federal do Tocantins / Campus de Miracema. Atuou como docente do ensino superior no Departamento de Serviço Social da UFSC e no curso de Serviço Social da Universidade Estadual do Tocantins - UNITINS. Ênfase em estudos e pesquisas sobre Método Crítico-Dialético; Formação Social Brasileira; Trabalho e "Questão Social"; Estado e Sociedade Civil \& Fundamentos do Serviço Social. 